\title{
Hypercalcaemia and phaeochromocytoma
}

\author{
B. J. FAIRHURST \\ M.D., F.R.C.P.
}

\author{
S. P. Shettar \\ M.B., B.S.
}

Royal Albert Edward Infirmary, Wigan

\begin{abstract}
Summary
A patient with a phaeochromocytoma associated with hypercalcaemia is described. The hypercalcaemia was corrected by removal of the phaeochromocytoma. Parathyroid hormone-like peptide was isolated from the tumour suggesting that ectopic parathyroid hormone production from the phaeochromocytoma was the explanation of the hypercalcaemia.
\end{abstract}

\section{Introduction}

The association of hypercalcaemia with phaeochromocytoma usually occurs as part of the multiple endocrine neoplasia syndrome type II, which includes medullary carcinoma of the thyroid, phaeochromocytoma and parathyroid adenomas or hyperplasia (Sipple, 1961). However, Swinton, Clerkin and Flint (1972) described a patient with hypercalcaemia which was corrected by removal of a phaeochromocytoma. Further reports of hypercalcaemia reversed by removal of phaeochromocytomas have been made (Kukreja et al., 1973; Ghose et al., 1976; Gray and Gillan, 1976). Kukreja et al. (1973) suggested that the hypercalcaemia was due to excess catecholamines stimulating the parathyroid glands to produce excess parathyroid hormone (PTH). This explanation has been challenged by Miller et al. (1975).

The authors now describe a further patient with a phaeochromocytoma associated with hypercalcaemia, which was corrected by removal of the tumour.

\section{Case report}

A 47-year-old male presented with a 6-month history of thirst and polyuria. He had also noted attacks of nocturnal sweating with palpitations occurring 2 or 3 times per week for 6 months. He had been receiving therapy for hypertension for the past 5 years-initially methyldopa, but for the past 3 years propranolol and a thiazide diuretic. There was no dyspnoea or weight loss. He had one brother who was normotensive.
Examination revealed a well nourished patient. His pulse was regular at $80 / \mathrm{min}$ and the blood pressure was $160 / 100 \mathrm{mmHg}$. There was no clinical cardiomegaly, oedema, neck vein distension, abdominal tenderness or palpable mass. The fundi were normal.

\section{Investigations}

$\mathrm{Hb} 15.8 \mathrm{~g} / \mathrm{dl}$; ESR $35 \mathrm{~mm}$ fall in one $\mathrm{hr}$; serum sodium $134 \mathrm{mmol} / \mathrm{l}$; serum potassium $4.2 \mathrm{mmol} / 1$; serum chloride $98 \mathrm{mmol} / \mathrm{l}$; serum calcium 3.54 $\mathrm{mmol} / \mathrm{l}$; serum phosphate $0.98 \mathrm{mmol} / \mathrm{l}$; alkaline phosphate $13 \mathrm{KAu}$.; urea $4.1 \mathrm{mmol} / 1$; urine calcium excretion whilst taking a normal ward diet was $14.5 \mathrm{mmol} / 24 \mathrm{hr}$; total serum proteins $74.4 \mathrm{~g} / \mathrm{l}$; serum albumin $41.8 \mathrm{~g} / \mathrm{l}$; glucose tolerance test revealed a mild diabetic curve with a fasting blood sugar of $7.8 \mathrm{mmol} / \mathrm{l}$ and a $2-\mathrm{hr}$ value of $11.1 \mathrm{mmol} / \mathrm{l}$; serum thyroxine $108 \mathrm{mmol} / 1$ (normal 61-165 mmol/l) $\mathrm{T}_{3}$ uptake 119; free thyroxine index 91 (normal 52-161). The urinary catecholamines were measured on 5 occasions; 24-hr excretion of free catecholamines varied from 100-810 $\mu \mathrm{g}$ (normal less than $100 \mu \mathrm{g})$ and the vanillyl mandelic acid excretion varied from 80-150 $\mu \mathrm{mol} / 24 \mathrm{hr}$ (normal 10-35 $\mu \mathrm{mol} / 24 \mathrm{hr}$ ). Chest X-ray was normal. No bone change seen on X-ray of hands. The i.v. urogram showed normal pelvi-calyceal systems and normal kidney shadows. There was a round soft tissue shadow above the right kidney. Aortogram revealed a highly vascular tumour $7 \mathrm{~cm}$ in diameter above the right kidney.

A diagnosis of hypertension due to phaeochromocytoma was made and initially medical treatment with atenolol $100 \mathrm{mg}$ daily and phenoxybenzamine $10 \mathrm{mg}$ daily was commenced.

Four months after the patient was first seen the tumour was removed and postoperative recovery was uneventful. The blood pressure reading fell to normal levels without hypotensive therapy. The serum calcium returned to normal after surgery (Fig. 1).

The tumour tissue was assayed for PTH-like activity producing a figure of $2 \cdot 8 \mu \mathrm{g} / \mathrm{g}$ of dried tissue. 


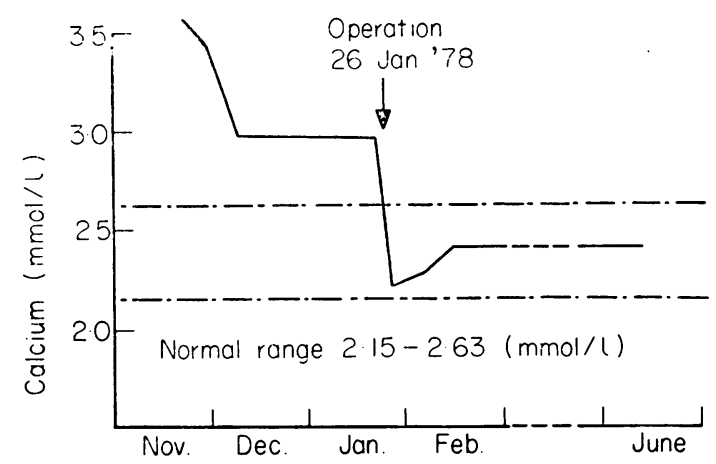

FIG. 1. Serum calcium tefcre and after operation.

\section{Discussion}

The patient's hypercalcaemia was corrected by removal of a phaeochromocytoma. This resembled the cases described in the literature (Swinton et al., 1972; Kukreja et al., 1973; Ghose et al., 1976; Gray and Gillan, 1976) and was not an example of multiple endocrine neoplasia. The demonstration of PTHlike activity in the tumour tissue at levels similar to those described in the ectopic PTH syndrome, $0.75 \mu \mathrm{g}-8.9 \mu \mathrm{g} / \mathrm{g}$ of dried tissue (Buckle, 1974), suggests that the patient's hypercalcaemia was due to PTH-like peptide production by the phaeochromocytoma. This explanation of the hypercalcaemia conflicts with the mechanism suggested by Kukreja et al. (1973): they suggested that excess circulating catecholamines stimulated the parathyroid to secrete parathyroid hormone. Bovine parathyroid slices exposed to catecholamines in vitro produced increased $\mathrm{PTH}$, as did acute infusion of $\beta$-adrenergic catecholamines in the cow and in man. Both effects are abolished by propranolol (Sherwood and Abe, 1972; Fischer, Blum and Binswanger, 1973; Kukreja, Hargis and Bouser, 1974). Miller et al. (1975) could not accept this explanation and concluded, after studying patients, that chronic circulating catecholamime excess does not cause increased PTH concentrations. They further suggested that ectopic production PTH by the phaeochromocytoma was a more likeby explanation. Ectopic production of PTH has been observed in many tumours, although $60 \%$ of cases occur with squamous cell carcinoma of the lung $\overline{\bar{g}}$. with kidney tumours. There has been no previogs description of ectopic PTH production occurriag in phaechromocytoma although this has been sưspected clinically in the past.

\section{Acknowledgments}

We are grateful to Dr Richard Buckle of Southamptक्ष General Hospital for estimating parathyroid hormotye concentrations in the tumour tissue.

\section{References}

BuCKLE, R. (1974) Clinics in Endocrinology and Metabolise, Vol. 3, no. 2, pp. 237-251.

Fischer, J.A., Blum, J.W. \& Binswanger, U. (1973) Acute parathyroid hormone response to epinephrine in viø.
Journal of Clinical Investigation, 52, 2434.

Ghose, R.R., Jemmett, J., Winsey, H.S. \& Woodhead, JS. (1976) Phaeochromocytoma and hypercalcaemia. Poorgraduate Medical Journal, 52, 593.

Gray, R.S. \& GiLlaN, J. (1976) Normotensive phaeochromgcytoma with hypercalcaemia: correction after adren omy. British Medical Journal, 1, 378.

Kukreja, S.C., Hargis, G.K. \& Bouser, E.N. (1974) Effet of adrenergic agents on parathyroid hormone secfetion in man (abstract). Clinical Research, 22, 473.

Kukreja, S.C., Hargis, G.K., Rosenthal, I.M. \& Willia G.A. (1973) Phaeochromocytoma causing excessive pafthyroid hormone production and hypercalcaemia. Ann बis of Internal Medicine, 79, 838.

Miller, S.S., Sizemore, G.W., Sheldon, G.S. \& TyCe, G. $\overrightarrow{\text { B. }}$ (1975) Parathyroid function in patients with phaechromocytoma. Annals of Internal Medicine, 82, 372.

SHERWOOD, L.M. \& ABE, M. (1972) Adrenergic receptors a the release of parathyroid hormone (abstract). Journal of Clinical Investigation, 51 (Suppl.), 88.

SipPle, J.H. (1961) Association of pheochromocytoma wifh carcinoma of thyroid gland. American Journal of Mediciñe, 31, 163.

Swinton Jr, N.W., Clerkin, E. \& Flint, L.D. (1972. Hypercalcemia and familial pheochromocytoma. C\&्ञ rection after adrenalectomy. Annals of Internal Medicine, 76, 45.5 . 